\title{
回収ボイラの事故例とその防止対策について
}

\author{
三菱重工秼 長崎造船所 貝 原 孝 明
}

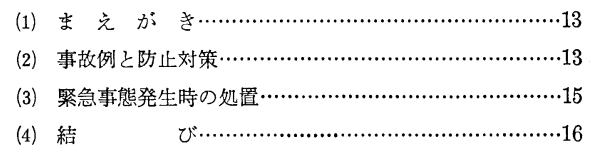

\section{（1） えがき}

近年，米国カナダを初め各国において，回収ボイラ 一の重大事故功発生し, 多くの人命を奪い, 致命的な 打撃を工場に与えている。米国，カナダのニーザ，メ 一カ，保険会社を主として組織されている BLRBAC (回収ボイラ諮問委員会) の調查によれば回収ボイラ の $20 \%$ が事故を発生したことを示している。

$$
\text { 1963-4 調査 }
$$

$\begin{array}{lcc}\text { 調査工場 } \quad 76 \text { 工場 } & 174 \text { 罐 } & \\ \text { 爆発を経験したボイラ } & 33 \text { 罐 } & \\ \text { 補助燃料の未燃ガス爆発 } & 16 \\ \text { 耐圧部からの漏水による爆発 } & 13 \\ \text { 操作ミスにより炬内に水や稀 } & \\ \text { 薄液を噴射して爆発 } & 4\end{array}$

わが国では幸い新聞紙上を賑わすという様な大事故 は経験されていないが，かなりの事故が発生したり， また発生の危機にさらされたことがあったのは事実で あり，当社が昭和 39 年アンケートによって調査した ころ 23 罐の中， 21 件といら予想以上の事故あるいは 事故発生の危機があったことが明らかとなった。その 内訳は次の通りであった。

事故または事故発生の危機を経験した件数 21 件

$$
\text { 内訳 } \begin{cases}\text { スメルト水接触爆発 } & 4 \\ \text { ガス爆発, 火炎 } & 4 \\ \text { デゾルバ爆発 } & 6 \\ \text { 空 罐 } & 7\end{cases}
$$

\section{（2）事故例と防止対策}

回収ボイラで発生した事故を大別すると次の 4 種に わけられる。

1. スメルト水接触爆発

2. 未燃ガスによる爆発

3. 老朽化による損賃事故

4. その他の事故

昭和 44 年 12 月

(2)

(2) -1 スメルト水接触爆発

スメルト水接触爆発は石炭，油，ガス等を燃料とす る一般ボイラに見られぬ回収ボイラ独特の爆発で，例 えば耐圧部の破損等により漏出した水が回収ボイラ炉 床の溶融スメルトと接触することによって発生するも のである。1961 年米国西海岸 Longview Fibre Co. の $670 \mathrm{~T} / \mathrm{D}$ 回収ボイラに発生した大爆発事故はこの 典型的なものであるが，これは給水不良のため火炬ス クリーンチューブがスラッジで閉塞し，過熱破損して 一挙に大量の水が炉床に流れ込んで溶融スメルトした ためで，ボイラは大きく破壊し，復旧には昼夜兼行作 業で 3 ケ月近くを要したと報じられている。

さてこのスメルト水接触爆発の機構については BL$\mathrm{RBAC}$ から研究を委託された $\mathrm{CE}$ 社, $\mathrm{B} \& \mathrm{~W}$ 社が 3 年がかりで試験研究を行なったが，その成果が 1966 年に一部公表された。

その発表によればスメルト水接触爆発の機構は溶融 した鉄に水が接触した時に発生する爆発と類似の物理 的反応が主因であることが判明したが，多大の日時と 莫大な研究費用を投じたにも拘わらず，その爆発機構

第 1 表 アメリカ, カナダの回収 ボイラ爆発事故数

\begin{tabular}{|c|c|c|}
\hline 年 & 補助然料の爆発 & スメルト水爆発 \\
\hline 1948 & 2 & 2 \\
1951 & 0 & 3 \\
1955 & 1 & 1 \\
1958 & 3 & 2 \\
1959 & 3 & 2 \\
1960 & 5 & 2 \\
1961 & 1 & 3 \\
1962 & 3 & 2 \\
1963 & 1 (小計19) & 2 \\
1964 & 2 & 4 \\
1965 & 1 & 4 \\
1966 & 0 & 6 \\
1967 & 0 & 2 \\
1968 & 0 & 0 \\
\hline 合 & 計 & 22 \\
\hline
\end{tabular}

和 
を完全には解明出来なかったし，また爆発を防ぐ有効 な手段も見出されず，今後更に研究が追加されようと

している情況にある。

スメルト水接触爆発は要するに炉内水が這入るか, また薄い黑液が噴射されることによって発生するもの であるので，この様な可能性のある原因を $1 つ 1 つ$ 除 くように努めることが現段階に郝けるこの爆発を防止 する唯一の道である。

炻内に水が這入った例としては前述のように，火炉 スクリーンチューブが，給水管理不良のため過熱破裂 した例，火炉チューブ，ボイラチューブが腐食とかス 一ツブロワのドレンカット等により減肉破裂した例, スメルトスパウトとか水冷式マンホールとかが破損し， 冷却水が炉内に這入った例等が上げられる。

また C E 社の研究によれば $55 \%$ 濃度以下（綮密に はスメルトの組成により 51〜60\% と変る) の黑液が 溶融スメルトと接触すれば爆発を発生することが報じ られているが，不良ノズルを使って稀薄な液を噴射し たため稀薄な状態のまま炉床の溶融スメルトに接触し た例とか，タンクに洗滌水が漏れこんでいることに気 付かず，黑液が薄められて炉内に噴射され爆発を発生 した例等も数多い。

変った事故例として過熱器噴破後炉床が冷えさらな いらちに漏洩假所発見の目的で水漲り水圧テストを行 なったため，この水が炬床に落下してスメルト水接触 爆発を発生した例があるので注意を要する。

また(2)-2 項にのべる未燃ガス爆発により耐圧部に 損傷を来たして，2次的にスメルト水爆発を起こした 例も報告されている。

わが国では原木材種等の関係でカスケード閉塞とい う外国に少い特異のトラブルあり，従ってカスケード の水洗湺を時々行なら必要があるが，この洗條中に黒 液焚を継続して, $50 \%$ 濃度程度の黑夜を直接灯内に噴 射することが従来より暫々行なわれて来た。最近この 洗激作業直後の運転操作に関連して, 重大事故が発生 しているので，カスケード洗湺時は重油専焼に切り替 公か，またカスケード洗滌時も少なくとも55\%濃 度以上の噴射黒液が確保でさるようにして頂くょう各 プラントに打願いしている。

(2)-2 未燃ガスによる爆発

未燃ガス爆発とは一般ボイラでしばしば経験する重 油やガス燃料の未燃ガス爆発と黒液から発生する未燃 ガス爆発との 2 つを指するのであるが，過去の事故例 より見るに前者が極めて重要と言兄る。更に回収ボイ ラの場合一般ボイラにない悪条件があることを留意し なければならない。経験によると次の 3 つの場合事故
が発生している。

(a) ボイラ起動時の補助燃料点火時

一般ボイラと同様で何等かの原因で失火し冘時は怇 内パージを充分に行ない失火原因を是正して正規の手 順で点火して行けば安全である。

（b）黑液噴射開始時

黒液加発生する水蒸気により燃燅空気が不活性化 され補助然料の火が消えかかったりまたは消えたり 乙勝ちであり，その際監視を怠ると補助燃料が未燃の まま多量に炬内に噴霧されることになり爆発発生の因 となる。

(c) 運転中ベッドが Black-out した時

未然ガス爆発はこの Black-out 時に最も多く発生 しているのでこの時の処置は特に注意が肝要である。 補助然料バーナ失火の過程は (b) 項の場合と大体同様 であるが (b) 項の場合より条件は一層苛酷でバーナ失 火を生じ易い。

Black-out が発生したら，その時の悷内の状態を充 分監視確認して，再点火の準備を計らねばならない。 若しこの時, 補助然料を助然中であったならば助然バ 一ナの焰の確認が第1 亿なされなければならない。 Black-out 時の処置は一般的に言えば黑液噴射を止め, 1 次空気量を充分增して，炉内を完全にパージして助 然バーナに点火することである。

未燃ガス爆発の代表的なものとしては 1963 年カナ ダの Rayonier Canada Ltd., Woodfibre 285T/D 回 収ボイラの 7 人死亡 2 人重傷という事故や 1958 年 East Texas P \& P 530T/D 回収ボイラの 11 人死亡 という痛ましい事故がある。

アメリカ, カナダで発生した爆発事故を調べると第 1 表のように, 1963 年迄は補助然料による未燃ガス爆 発とスメルト接触爆発が，注とんど同数であったのが その後急激に未燃ガス爆発が減少してきたことが分か る。これは一に回収ボイラ用の特殊イグナイタ付補助 燃料バーナが開発されたこと，BLRBAC の補助燃料 爆発防止小委員会によって緾められた「回収ボイラ起 動停止時の補助然料に関わるインタロック推奨案」が 多くの回収ボイラに採用されて来た結果と考えられる。 上記の助燃バーナは燃焼を常時監視するイグナイタ を個々のバーナ毎に備光たもので，バーナ燃焼中は常 時このイグナイタを燃やし続けてバーナの失火を防止 し，更に万一失火が発生した場合はこれを検出し各々 のバーナの供給燃料を即時遮断して，未燃燃料の炉内 流入を阻止し，安全をはかるものである。当社では米 国で開発されたこの種イグナイタを更に改良したもの を完成したが，既に本イグナイタが国内の 4 罐に採用 
された。今後わが国でも, 安全対策の一つとして本方 式が新設ボイラのみならず既設ボイラにも採用される ことになると考光る。

米国カナダでは過去 3 ケ年以上にわたり全く補助燃 料による未燃ガス爆発が消隇したのでBLRBACの 補助燃料爆発防止小委員会は現在活動を休止中である。

(2)-3 老朽化による損傷

本項は回収ボイラの寿命といらことに関連する。回 収ボイラは特殊の腐蝕性燃料を焚き, また過負荷運転 を行ならチャンスも多いので一般ボイラに比べ寿命は かなり短いとい光る。

回収ボイラで最初にいたむのは耐圧部では過熱器の 高温部（特に火炉の熱輻射を直接うける部分）。火炉 下部のスメルト腐蝕を受ける部分。節炭器の低温部分 である。非耐圧部も早く腐蝕されスメルト漏洩, 黒液 漏洩，ガス漏洩の因となる。

回収ボイラの寿命はボイラの運転状況（黒液の性状， オーバーロード，発停の頻度）並びに保守の良否によ るので一概に言えないが，国内K P プラントを通覧し， 10年程度稼動した回収ボイラは大体かなりの補修改造 が加えられているようである。勿論, SP, SCP, CGP 廃液などが混焼されれい゙寿命忹もっと短くなろう。

いずれにしても事故を未然に防止するためには充分 な点検, 保守が推奨される。当社としては $1 \sim 2$ 年ご とに火炉水管や過熱器管の抜取肉厚計測を奨めたいし， また数年ごとには要所要所を切り取って詳細調査やま た酸洗いの要否を確認することも必要と考学る。

(2)-4 その他の事故

回収ボイラとい党どもボイラに相違ないので一般の ボイラで発生する事故は当然起るわけである。給水不 良によるスケールトラブル, 溶存酸素によるチューブ 内面の腐蝕, 酸洗施工不良による腐蝕発生, 火災, 低 水位による空罐事故などもしばしば耳にすることがあ るのでこの点保守運転に充分注意が払われねばならな い。

また国内では聞かないが米国, カナダなどではカス ケードェバポレータ並びにその周辺㖶道に火炎があっ たと聞く。これは油燃焼時とか停罐直後に発生するこ とがある由で排ガス温度に注意しておけば発見できる ことであるが，カスケード前後の煙道潦気が吹込め るような設備を予め設けておけば万一の場合に役立つ であろう。

\section{（3）緊急事態発生の処置}

ボイラに緊急事熊が発生したとき例えば耐圧部に漏 洩が始まった様な時にボイラを如何に安全に停止す
るかその緊急停止手順切研究する小委員会が BLRBAC の中にあり活動を続けている。

何か回収ボイラに事故が㐫って停罐したという情報 が這入れば，直ちに BLRBACよりその工場あて質問 書が送られる。その回答について検討を重称その事故 がスメルト水接触爆発であったか，未燃ガスの爆発で あったかなどを判定し併せて停止手順が妥当であった かどうかといった討議を加光て，BLRBAC で定めた 緊急停止手順案に反映させて行くといった方法が取ら れている。

第 2 表 回収将イラ毉急停止手順

(1968.4)

つぎの場合には直ちに緊急停止を行うこと。

（1）少量の水であっても炉内に這入っていること が分って，それを直ちに止めることが出来ない 場合。

（2）耐圧部に少しでも漏洩があることが発見され た場合。但し検查孔のガスケットや，水面計な ど炉外へ漏水している場合はこの限りではな い。

緊急停止手順は次の通り。

1、警報をならして, 関係者以外は回収ボイラ周 辺から立退かせる。

2.すずての燃料を直ちに遮断する。補助燃料系 統の遮断はボイラから離れた場所で行らこと。

3.ボイラへの給水を直ちに止める。

4. a 黑液をべッドに浴びせて火を消す方法「ス マツザー法」を使用する場合は直ちにF D フ ンをトリップさせ更に

・F D ダンパを全閉にして空気の供給を止め る。

・I Dファン又はダンパを調整して炉内を負圧 に保つ。

・ベッドに浴びせる黒液は常に最低 $55 \%$ Solid 以上の濃度のものであること。

5. ボイラから出来るだけ早く排水する。排水は 炉底から 8 フィート $(2400 \mathrm{~mm})$ の高さまで行 うこと。

現在制定されている手順は 1968 年春の大会で決定 されたもので第 2 表に示すよらなるのである。ここで 過去に発生した事故例がこの手順にどのように取り入 れられてきたかを例示し乍ら $2 ， 3$ の解説を加える。

この手順で最も重要なことは「ほんの僅かな量の水 でも炉内に這入っていることを発見したら緊急停止手 順に従って直ちに停罐すること」を推奖していること である。漏水個所を探し迴ったり，またボイラを停止 すべきかどうかと迷っている間に爆発が起って死亡者 
や負稘者が出た事故例があるので，この様に「直ちに 緊急停止を行ならこと」と決められたのである。

手順 1 で警報によってプラント訪問者を含め関係者 以外はすべて建家外に退避することができるようにし ておくことが強調されている。これはパネルの傍で運 転員と話していた人が爆発で怪我をした事故があった からである。勿論運転員はこの警報によって予め定め られた部署につくよら日頃からよく訓練されて执く必 要があることは言うまでもない。

手順 2 については補助然料の遮断弁をボイラから充 分離れた所に位置させて打くことが述べられている。 これは火炉爆発によってボイラ近辺にあった重油管が 破損して，火災が発生し反って大きな損害を来した事 故があったからである。

また手順 5 は今までの常識から言えば反って危険と 考えられることであるが，C E 社などメーカはテスト 結果より判断しボイラには何等の損傷も生じないであ ろらと述べている。もちろん，この様な非常措置を講 ずるのはボイラーの一生にそら数多くあるものではな いといら前提があってのことであるが，またこの手順 5 はこの非常排水を行ならために特別な遠方操作弁が 設備されているボイラのみに実施することであって， 火炉の管寄せのドレン弁を開けるため人が現場に行く ようなことは絶対にしてはならないことは言うまでも ない。といらのは火炉爆発によって炉底部が開口する ようなことがあり非常に危険であるからである。

上記の BLRBAC で定めた緊急停止手順は暫定とい らことになっているが，これは新しい経験が積まれる 毎に見直し修正を加えるという意味であり，今迄も何 回となく改正が加えられた様に今後も新しい型の事故 が発生すればその体験がとり入れられて改正が加えら
れることになる。

しかし少なくとも現在ではベストの案と考えられて いる。

国内の各社に於かれても，これらをもとにして，各 社の事情に適した手順を早急に樹立され，万一の場合 に備觉られることを是非打願いしたい。

\section{(4) 結}

\section{び}

回収ボイラは一般ボイラと異って特殊然料を使用す るがために事故発生のチャンスが多く，特に優秀な運 転者が必要とされるわけである。

わが国の回収ボイラも米国のあとを追って大容量化 に向いつつあるがベテラン運転者の数は年々減少しつ つあり，またボイラ運転人員も削減の傾向がより強ま ると予想されるだけに，米国カナダのわだちを踏むこ とがないよう設備面に，より改善を計ると共に保守点 検にまた運転者の訓練に一層，力を注ぐ必要があると 感じる。

当社としては外国の事故例や経験で日本国内のプラ ントに参考に出来るものがあれば設計に反映させ，ま たユーザにも報告して設備改善や保守点検などに役立 てて頂くよう心掛けている。

最近回收ボイラの安全操業について各工場の認識が とみに深まり, 事故防止のための作業基準が整備され， また運転員教育訓練にも力を入れて扣られる工場が増 加しつつあるのはまことに喜ばしいことである。

安全操業の問題はユーザとメーカが力を併せて研究 するのでなければ効果が上らないものであるので，ご 指導ご協力を切に打願いする次第である。

（原稿受付 昭 44.9.16）
新 刊 紹 介

印写工学 II 信号变換拈よび伝送論 和田正信編共立出版秼発行

A 5 版，ビニール装，本文 282 ページ， 索引付定 価 1,800 円

情報産業のなかで，情報を可視イメージ化し人間の 視覚に訴兄て情報の認識, 整理, 保存, 判断, 交換, 伝導，要するに人間同志の Communication system る関する技術を科学的に取扱らのが「印写工学」であ り，そのらち印刷が最も古くから親しまれている。広
い意味の印刷技術を，化学的方法，電子的方法，磁気 的方法, 熱的方法, 粒子的方法の各章に分けて, 著者 （東北大教授）々本多（東大助教授），小門（工大助教 授)，中村 (早大教授)，金城(キャノン侏技師)，菊池 (東京写大教授) の各博士が分担して執筆された。引 用の内外文献が実に豊富である。これは編述が良心的 であることを示して和り，読者を安心させると同時に， 著者の希望する読者の「新らしい可能性の実用面への 展開」照を有効に刺战するのに大いに役立っているよ らと思われる。

（松井 満） 